$\mathbb{T}$ periodica polytechnica

Civil Engineering

$54 / 1(2010) 53 \quad 60$

doi: 10.3311/pp.ci.2010-1.06

web: http://www.pp.bme.hu/ci

(c) Periodica Polytechnica 2010

RESEARCH ARTICLE

\section{Effect of heating on the physical properties of asphalt aggregates}

Gabriella Devecseri

Received 2009-05-29, revised 2009-06-22, accepted 2009-06-29

\begin{abstract}
Asphalt is defined as a mixture of inert mineral matter, such as aggregate, mineral filler and bituminous binder in predeterminated portions. One of the most important properties of asphalt mixtures is the bitumen content. The most preferred way of asphalt binder analysis is extraction (with tricloroethylene). Because of environmental reasons extraction should be replaced with more environment friendly solution, this could be heating. But high temperatures can cause changes in the physical properties of mineral aggregates that are commonly used in asphalt mixtures causing faults in the results of the binder analysis. Eight different types (five andesites, one basalt, two dolomites) of Hungarian rocks have been tested in laboratory conditions to analyse the effect of heat on asphalt aggregates. $11 / 16 \mathrm{~mm}$ fractions were heated at $480^{\circ} \mathrm{C}$ in an ignition furnace. The weight losses and grain distributions were recorded and compared. The physical parameters have shown that aggregates behave differently after burning on high temperature.

As an additional result coloures and colour differences of aggregates were also observed after heating.
\end{abstract}

\section{Keywords}

asphalt aggregates $\cdot$ physical properties $\cdot$ ignition furnace . weight loss $\cdot$ grain distribution

\section{Gabriella Devecseri}

Department of Highway and Railway Engineering, BUTE, Múegyetem rkp. 3. Budapest, H-1521, Hungary

e-mail: devecseri@uvt.bme.hu

\section{Introduction}

Asphalt mixtures consist of aggregate, mineral filler and bituminous binder in predeterminated portions. The asphalt binder analysis is a vital part of the quality control. One of the most important properties of asphalt mixtures is the bitumen content, because it has a sensitive effect on the quality and the price of the pavement. Many ways of asphalt binder measurements exist e.g. solvent extraction using trichloroethylene (with or without a solvent recovering reclaimer), solvent extraction using an alternative solvent, ignition oven, ignition oven and solvent combination [7]. The most favourables in the present quality control practice are:

1 extraction and

2 burning.

Unfortunately none of these solutions are perfect. Although with extraction it is possible to assess two important properties of asphalt mixtures: the bitument content and the grain distribution, usualy hydrocarbon compounds are used for the analysis. In Hungary as in most of the countries this compound is tricloroethylene which has been identified as carcinogenic and environmentally hazardous, contributing to the depletion of the ozone layer. The storage of these compounds is quite difficult, in some countries it is not solved yet. Consequently, tricloroethylene will likely be banned in the future. Therefore, in order to maintain present testing methods, a less hazardous and suitable replacement for tricloroethylene needs to be found [2].

In the last decade an alternative has appeared to solvent binder extraction. Asphalt binder analysis done by special ovens started to become popular instead of extraction as burning has less effect on the environment, although this methodology is not that exact as extraction. Several factors can influence faults in the final bitumen content result. The main reasons are the followings:

1 An error caused by burn out of materials within the aggregate itself.

2 Depending on the type of aggregate the result can be different.

3 Different sizes of aggregates behave differently. 
During heating the bitumen burns out at arround $450^{\circ} \mathrm{C}$. Thermal behaviour of asphalt mixtures have been examined previously [3, 6, 9], but the thermal behaviour of aggregates themselves, especially the effects of high temperatures on asphalt aggregates have not been examined in detailes yet. Detailed analysis on whether physical and minerological properties of asphalt aggregates change during the analysis has not been done previously. My aim was to collect more knowledge from the behaviour of Hungarian asphalt aggregates.

\section{Methods and materials}

The effect of heat was studied on eight Hungarian types of stones. From the aggregates the $11 / 16 \mathrm{~mm}$ fraction was examined (as this size of the aggregates is frequently used in asphalt mixtures, and they are big enough to be measured). From the aggregates 10 x $1000 \mathrm{~g}$ portions were prepaired (washed, and dried) from each type of rocks for burning according to the Hungarian Standard (MSZ EN 12697-39:2005). The test portion was placed in steel basket which was then placed in the furnace. The portions were burned in a special oven (ABA/75 Carbolite Asphalt Binder Analyser) at $480^{\circ} \mathrm{C}$ while weight loss was recorded until the weight becomes constant. The ignition furnace consists of a combustion chamber with an integral balance located bellow. The balance contains software to monitor the rate of weight loss ( $\left.W_{\text {loss }}\right)$ during the test. Once the sample has reached a predetermined constant mass point the test is automatically stopped. The test conditions fully reflected the processes that take place during bitumen content analysis.

Rate of Weight Losses were calculated with the following method. (This methodology is used when the examined material is fully dried at $110^{\circ} \mathrm{C}$ to stable weight before heating.)

The original weight $\left(W_{S}\right)$ of samples before heating:

$$
W_{s}=W_{t+s}-W_{t}
$$

where

$W_{s}$ is the dry weight of sample before heating in gramme $(\mathrm{g})$,

$W_{t+s}$ weight of sample and steel basket together before heating in gramme $(\mathrm{g})$,

$W_{t}$ weight of steel basket before heating in gramme $(\mathrm{g})$.

The rate of Weight Loss $(W L)$ is calulated with the following formula:

$$
W L=\frac{W_{s}-W_{a}}{W_{s}} \cdot 100=\frac{W_{\text {loss }}}{W_{s}} \cdot 100
$$

where

$W L$ is the percentage of weight loss of the heated sample (\%),

$W_{s}$ dry weight of samples before heating in gramme $(\mathrm{g})$,

$W_{a}$ weight of sample after heating in gramme $(\mathrm{g})$,

$W_{t}$ weight of steel basket before heating in gramme $(\mathrm{g})$,
$W_{\text {loss }}$ weight loss measured by the integral balance in gramme (g).

After heating the portions were cooled down on $22^{\circ} \mathrm{C}$ to become ready for sieving. In each case sieving took half an hour (hole sizes of strainers were the followings: $0 \mathrm{~mm}$, $0.063 \mathrm{~mm}, 0.125 \mathrm{~mm}, 0.250 \mathrm{~mm}, 1 \mathrm{~mm}, 2 \mathrm{~mm}, 4 \mathrm{~mm}, 5.6 \mathrm{~mm}$, $8 \mathrm{~mm}, 11.2 \mathrm{~mm})$. The grain distribution of the burned portions was measured and recorded after sieving. After the end of the examination 8x10 grain distribution and weight loss data were available for the analysis.

Grain distribution can be determined with the folowing equation:

$$
P P=\frac{\sum_{i=1}^{n} R_{i-1}}{M} \cdot 100
$$

where

$P P$ is the percentage, by mass, of particles passing a particular size of strainer $(\%)$,

$R_{i}$ cumulated weight of passing particles $(\mathrm{g})$,

$M$ total weight of sample before sieving in gramme $(\mathrm{g})$,

$n$ number of strainers ( 1 is the $0 \mathrm{~mm}$ particle size, $\mathrm{n}$ is the $16 \mathrm{~mm}$ particle size).

Photographs were also made before and after heating.

\subsection{Description of stones}

Asphalt aggregates are those materials used in asphalt pavements. During this analysis eight Hungarian types of aggregates were examined which correspond to the most widely used pavement materials in this country. The most important parameters of studied aggregates are given in Table 1. Los Angeles (LA) coefficients of aggregates are mentioned in the table, because this value describes the resistance to mechanical fragmentation of the rocks. The lower the coefficient the more resistance the aggregates have to mechanical fragmentation.

In most of the cases andesite and basalt is used in asphalt mixtures as aggregates. But as Hungary is rich in dolomite and because the price of effusive rocks are three or four times higher some reasearches started to go on to discover whether asphalt mixtures with dolomite aggregates can reach the same quality as other mixtures, or could they be used somehow as pavement material. So the better understanding of different aggregates is fundamental either for the asphalt industry or for the economy.

\section{Results}

Changes in physical properties can be divided into three main categories:

1 changes in grain distribution,

2 changes in weight,

3 colour changes. 
Tab. 1. Most important parameters of examined aggregates

\begin{tabular}{|c|c|c|c|c|c|c|}
\hline Nr. & Name & Type & Colour at $22^{\circ} \mathrm{C}$ & Typical Minerals & $\begin{array}{l}\text { Bulk Density } \\
\qquad\left[\mathrm{kg} / \mathrm{m}^{3}\right]\end{array}$ & $\begin{array}{c}\text { Los Angeles } \\
{[\mathrm{m} \%]}\end{array}$ \\
\hline 1. & Komló & Andesite & Greyish black & $\begin{array}{c}\text { Plagioclase, Amfibole, } \\
\text { Piroxene, Biotite }\end{array}$ & 2650 & 14,25 \\
\hline 2. & Nógrádkövesd & Andesite & Greyish black & $\begin{array}{c}\text { Plagioclase, Amfibole, } \\
\text { Piroxene, Biotit }\end{array}$ & 2700 & 16,21 \\
\hline 3. & Recsk & Andesite & Greyish black & $\begin{array}{c}\text { Plagioclase, Amfibole, } \\
\text { Piroxene, Biotit }\end{array}$ & 2700 & 15,82 \\
\hline 4. & Szob & Andesite & Greyish black & $\begin{array}{c}\text { Plagioclase, Amfibole, } \\
\text { Piroxene, Biotit }\end{array}$ & 2550 & 14,39 \\
\hline 5. & Tállya & Andesite & Greyish black & $\begin{array}{c}\text { Plagioclase, Amfibole, } \\
\text { Piroxene, Biotit }\end{array}$ & 2650 & 19,07 \\
\hline 6. & Uzsa & Basalt & Greyish black & $\begin{array}{c}\text { Plagioclase, Piroxene, } \\
\text { Olivine }\end{array}$ & 2750 & 13,23 \\
\hline 7. & Gánt & Dolomite & White & Dolomite & 2750 & 16,00 \\
\hline 8. & Iszkaszentgyörgy & Dolomite & Jonquil & Dolomite & 2750 & 17,70 \\
\hline
\end{tabular}

\subsection{Changes in grain distribution}

According to the laboratory tests, it can be established that the grain distribution of the rocks changes after burning on $480^{\circ} \mathrm{C}$. Table 2 and Figs. 19 represent the average, the minimum and maximum grain distributions of the examined rocks (the end of the diagrams of grain distributions has been cut off as percent passing reaches $100 \%$ above $11,2 \mathrm{~mm}$ in each case). According to the grain distribution diagrams weathering of stones can be expected between $0,05 \%$ and $4 \%$. The average of breaking is less than $3 \%$.

Weathering of Tállya andesite varied between $0,35-1,77 \%$. Average of the results was $1,27 \%$. Deviation of the measured values was $0,45 \%$.

It was observable to the eye and the it has also been appeared in the results that weathering of Szob andesite was the highest among the stones. In case of Szob andesite broken quantities reached 2,18-3,58\%. Average reached 2,81\%. Deviation of the values was $0,48 \%$.

The smallest weathering among effusive rocks but also among the examined aggregates was measured in case of Nógrádkövesd andesite $(0,05-0,75 \%)$. Average of grain distributions was $0,31 \%$. Deviation of the results was only $0,27 \%$.

Weathering of Iszkaszentgyörgy dolomite reached 0,59$1,39 \%$. Average of the results was $0,95 \%$. Deviation was $0,30 \%$.

It was also visible to the eye and it also can be seen in the results that the smallest weathering among dolomites was measured in case of Gánt dolomite $(0,08-0,77 \%)$. Average of the results was $0,31 \%$. Deviation of the results was the lowest in case of this type of stone $0,21 \%$.

Values of weathering in case of Recsk andesite varied between $0,23-1,80 \%$. Average of the results was $0,88 \%$. Deviation of the values was $0,51 \%$.

Weathering of Komló andesite was 0,44-2,49\%. Average was
$1,47 \%$. The highest $(0,73 \%)$ deviation was measured in case of this type of stone.

Weathering of Uzsa basalt varied between $0,32-2,23 \%$. Average of grain distributions was $1,63 \%$. The deviation of this stone was the second highest $(0,62 \%)$ among the examined rocks.

The highest weathering rate was measured among effusive stones. Andesite from Szob has reached almost $4 \%$ of breaking, while the worse of the dolomites has not reached $1,5 \%$. The minimum weathering was $0,05 \%$. This value was measured among effusive stones (Nógrákövesd andesite), but small weathering rate was measured also in case of Gánt dolomite. Uzsa basalt behaved as the average.

\subsection{Weight losses}

The laboratory test has shown that the examined rocks change their weights during burning on $480^{\circ} \mathrm{C}$. According to final results of weight losses (Figs. $10+11$ and Table 3 the effusive stones lose the $0,04 \%-1,28 \%$ of their original weights, while the sedimentary aggregates do not have relevant weight losses. On the contrary although in a very little rate but hihger weights were measured after heating dolomites. The highest weight loss $(1,28 \%)$ was measured at Szob andesite, but the basalt had also higher weight loss $(1,10 \%)$. Among effusive stones the least weight loss was measured in case of Komló andesite. It was also the andesite of Szob where the most significant difference between the minimum and maximum values of weight losses was observed.

\subsection{Colour changes}

An additional result of the laboratory tests was the colour chage of aggregates (Table 4). Some of the aggregates show very distinct colour changes which is visible to the naked eye. Dolomites have white, yellowish (jonquil) colours at room tem- 
Tab. 2. Weathering of examined aggregates

\begin{tabular}{ccccccc}
\hline \multirow{2}{*}{ Name } & Type & $\begin{array}{c}\text { Number of } \\
\text { Samples } \\
\text { [pieces] }\end{array}$ & Average & Deviation & Minimum & Maximum \\
\hline Komló & Andesite & 10 & 1,47 & 0,73 & 0,44 & 2,49 \\
\hline Nógrádkövesd & Andesite & 10 & 0,31 & 0,27 & 0,05 & 0,75 \\
\hline Recsk & Andesite & 11 & 0,88 & 0,51 & 0,23 & 1,80 \\
\hline Szob & Andesite & 10 & 2,81 & 0,48 & 2,18 & 3,58 \\
\hline Tállya & Andesite & 10 & 1,27 & 0,45 & 0,35 & 1,77 \\
\hline Uzsa & Basalt & 10 & 1,63 & 0,62 & 0,32 & 2,23 \\
\hline Gánt & Dolomite & 10 & 0,31 & 0,21 & 0,08 & 0,77 \\
\hline Iszkaszentgyörgy & Dolomite & 10 & 0,95 & 0,30 & 0,59 & 1,39 \\
\hline
\end{tabular}

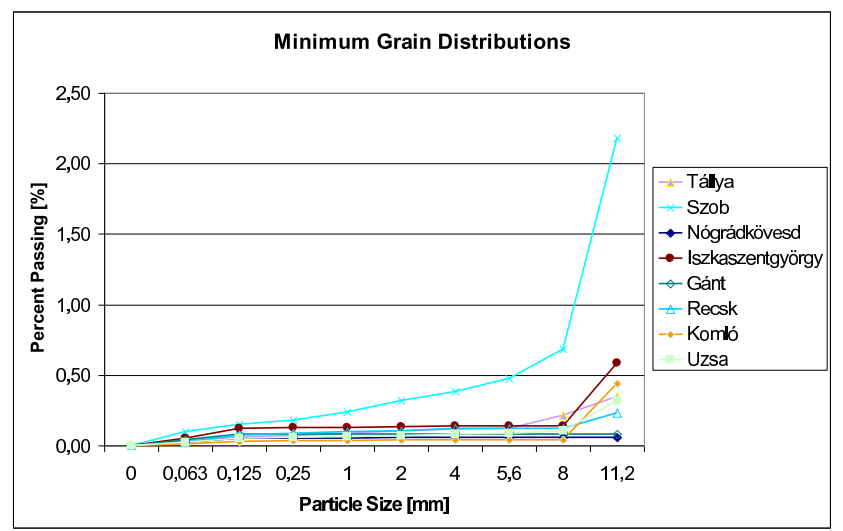

Fig. 1. Minimum grain distributions of heated aggregates

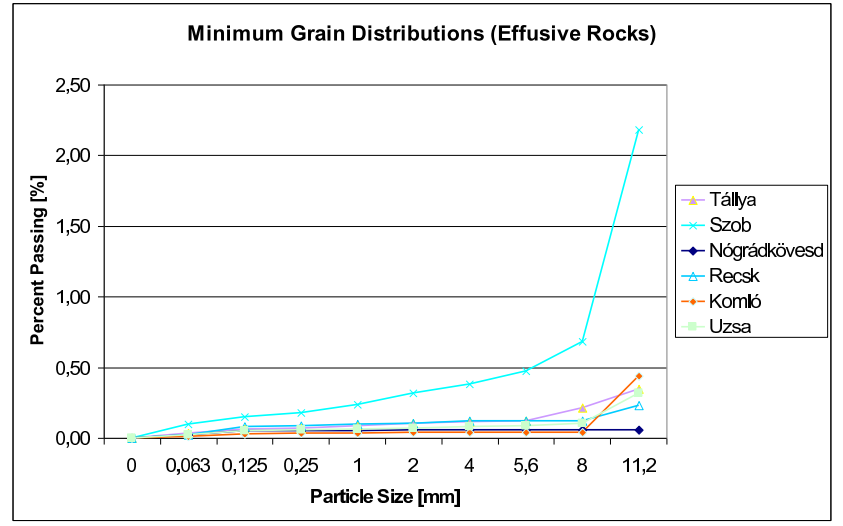

Fig. 2. Minimum grain distributions of heated aggregates (effusive rocks)

perature but at $480^{\circ} \mathrm{C}$ the colours turned to pinkish. Andesites, and basalt also change their colours from grey or black to brownish or to greenish. Colour changes have mineralogical reasons.

\subsection{Discussion}

Heating of aggregates to $480^{\circ} \mathrm{C}$ causes changes in the original grain distributions of the stones because of weathering.

Weathering in this case does not depend on the type of stone.
It was expected that weathering of dolomites are more than the effusive rocks as they are known as less lasting stones, but trend could not be discovered.

To compare grain distributions with the Los Angeles values, relation can not be set out between the mechanical and the thermophysical behaviour of the stones. The best example is the Szob andesite with its third best Los Angeles rate and its highest thermophysical weathering. 


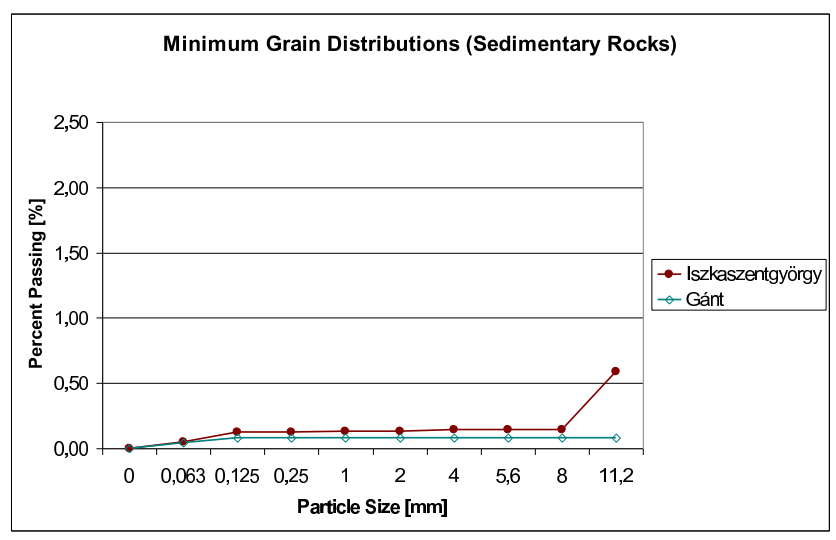

Fig. 3. Minimum grain distributions of heated aggregates (sedimentary rocks)

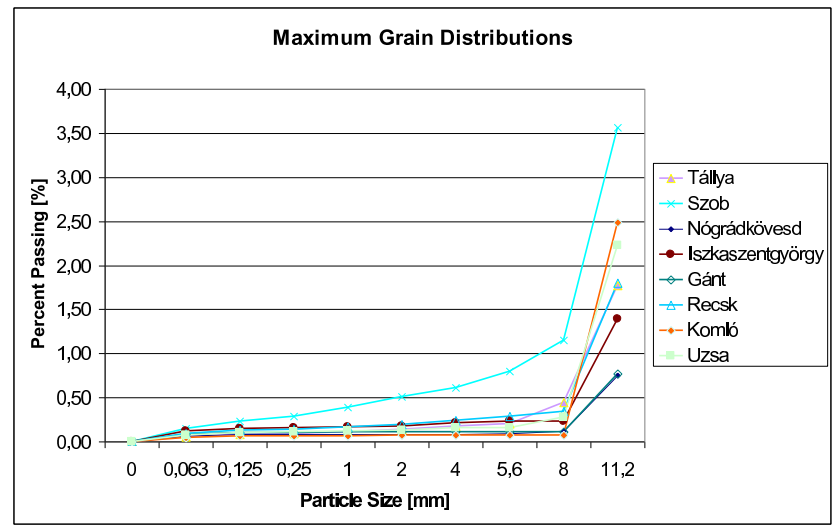

Fig. 4. Maximum grain distributions of heated aggregates

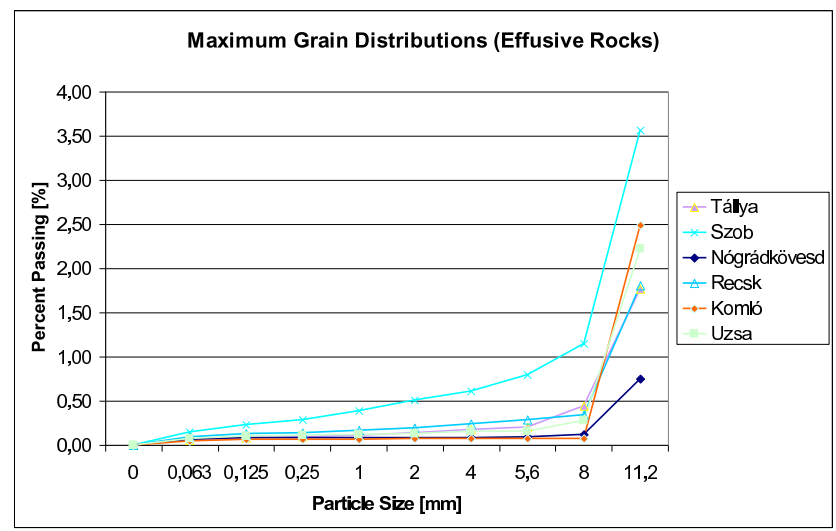

Fig. 5. Maximum grain distributions of heated aggregates (effusive rocks)

According to the laboratory tests the best thermophysical behaviour had the Nógrádkövesd andesite but the Gánt dolomite behaved almost the same.

In these experiments not only thermal breaks have been documented but also changes in weights of aggregates. After heating weight losses were recorded for effusive rocks, and stable weights, or weight growing for sedimentary rocks. This suggests that the sedimentary rocks can absorb air moisture during heating, while in effusive rocks organic parts, or minerals burns out.

Based on the results it can be established that heating does not have a significant influence on the behaviour of Gánt dolomite, but it has notable effect on the physical properties of Szob andesite.

These experiments have shown that type of aggregates does not necessarily show a uniform trend, a uniform behaviour. 


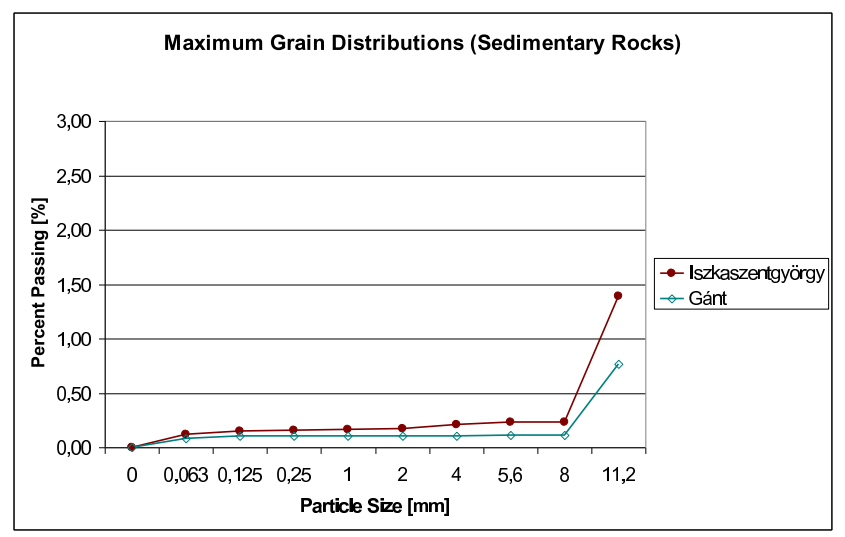

Fig. 6. Maximum grain distributions of heated aggregates (sedimentary rocks)

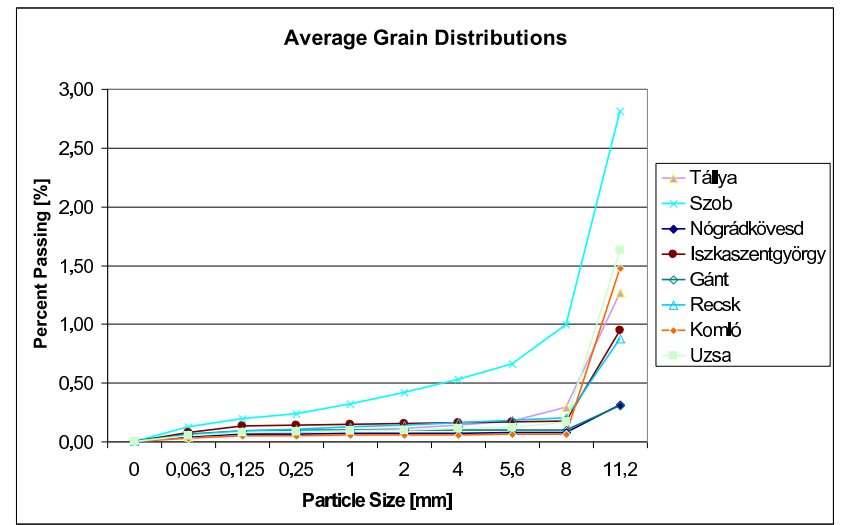

Fig. 7. Average grain distributions of heated aggregates

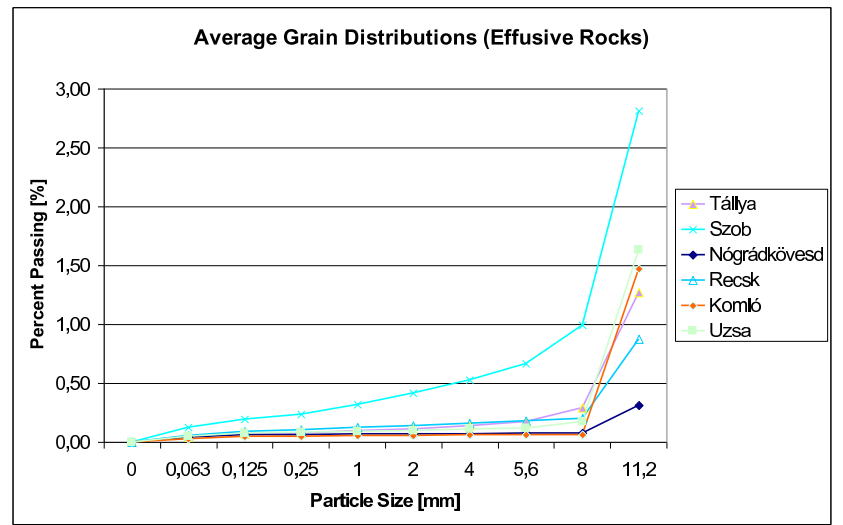

Fig. 8. Average grain distributions of heated aggregates (effusive rocks)

During these examinations macroscopic colour changes were also documented. Changes were observed both on effusive and sedimentary rocks. It depends on the mineralogical contents of the stones whether their original colours change during heating. The most common was the transformation of the original colour to reddish, which is the result of the transformation of ferrooxids, but the transformation of mangan and organic parts can cause colour changes too [1,8].
When iron is present as ferri-oxy-hydroxid (goethite) it often transforms to ferro-oxid (hematite), while the water dissapears. Changes start at $200-300^{\circ} \mathrm{C}[1,8]$. Transformation of organic parts to carbon starts at arround $500^{\circ} \mathrm{C}$ [1, 8].

\subsection{Conclusions}

The most important establishments in relation with the thermophysical behaviour of aggregates are the followings: 


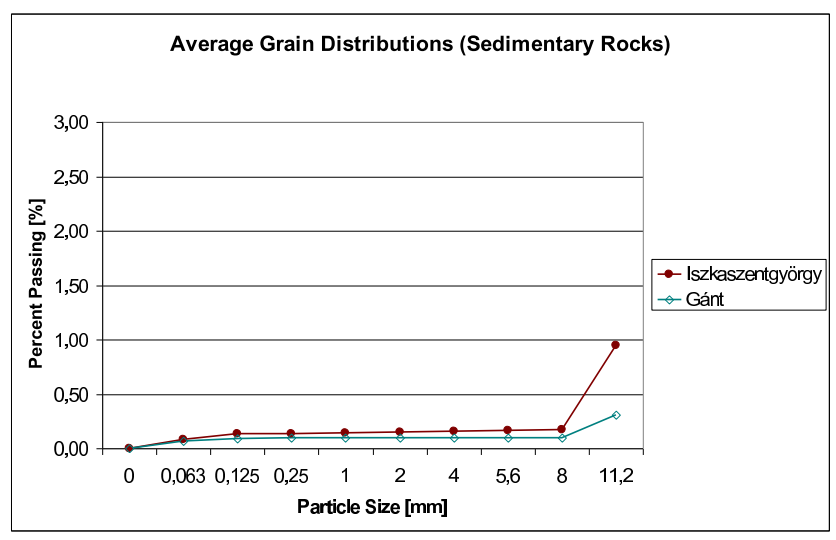

Fig. 9. Average grain distributions of heated aggregates (sedimentary rocks)

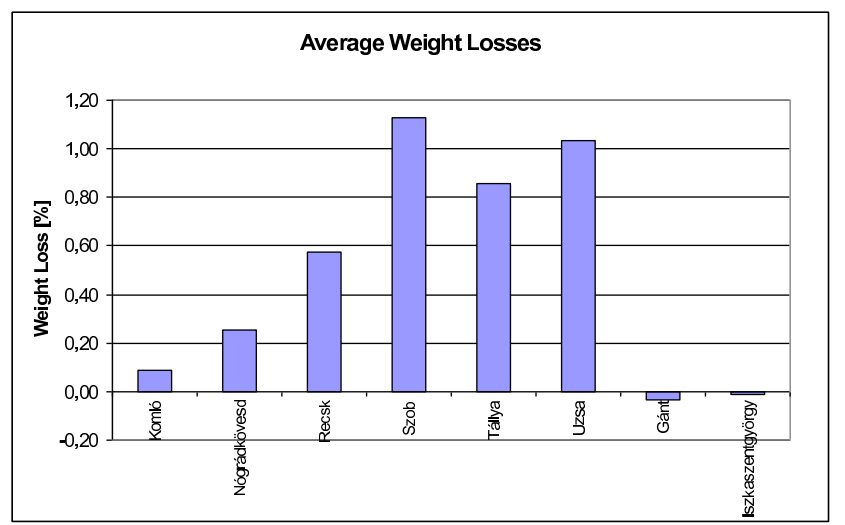

Fig. 10. Average weight losses of aggregates after heating at $480^{\circ} \mathrm{C}$

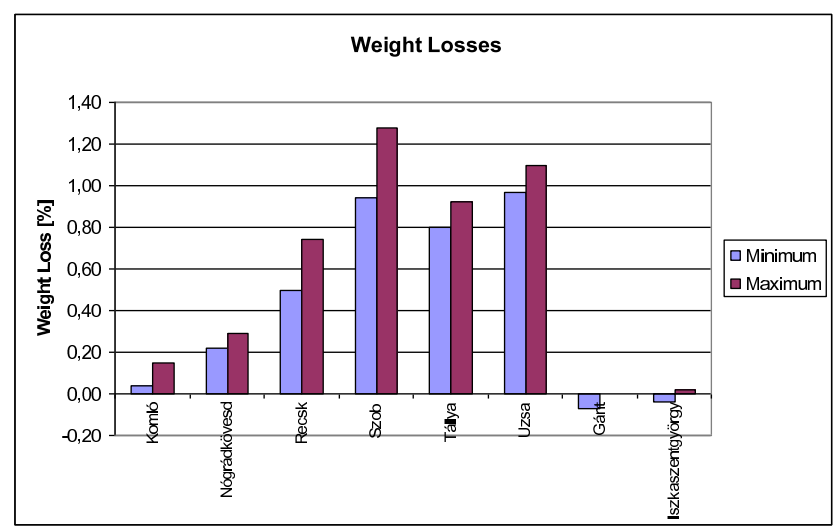

Fig. 11. Minimum and maximum weight losses of aggregates after heating at $480^{\circ} \mathrm{C}$

1 High temperatures cause mineralogical and physical changes in the asphalt aggregates.

2 Weathering of aggregates was observed after heating them at $480^{\circ} \mathrm{C}$. Percentage of weathering is less than $4 \%$ in case of $11 / 16 \mathrm{~mm}$ fractions of examined aggregates.

3 Effusive rocks have weight losses during heating, because organic or mineral parts burn out, while under nearly the same circumstances weights of sedimentary rocks are stable.

4 It can not be stated that the effusive rocks have better quality than the sedimentary rocks, at least according to their thermophysical behaviour.

5 There is no relation between the Los Angeles values and the thermophysical behaviour of aggregates.

6 Indirectly lasting of pavements also depends on the thermo- 
Tab. 3. Weight losses of aggregates

\begin{tabular}{ccccccc}
\hline \multirow{2}{*}{ Name } & Type & $\begin{array}{c}\text { Number of } \\
\text { Samples } \\
\text { [pieces] }\end{array}$ & Average & Deviation & Minimum & Maximum \\
\hline Komló & Andesite & 10 & 0,09 & 0,04 & 0,04 & 0,15 \\
\hline Nógrádkövesd & Andesite & 10 & 0,25 & 0,02 & 0,22 & 0,29 \\
\hline Recsk & Andesite & 11 & 0,57 & 0,07 & 0,50 & 0,74 \\
\hline Szob & Andesite & 10 & 1,13 & 0,09 & 0,94 & 1,28 \\
\hline Tállya & Andesite & 10 & 0,86 & 0,04 & 0,80 & 0,92 \\
\hline Uzsa & Basalt & 10 & 1,04 & 0,04 & 0,97 & 1,10 \\
\hline Gánt & Dolomite & 10 & $-0,03$ & 0,02 & $-0,07$ & 0,00 \\
\hline Iszkaszentgyörgy & Dolomite & 10 & $-0,01$ & 0,02 & $-0,04$ & 0,02 \\
\hline
\end{tabular}

Tab. 4. Colour changes of aggregates

\begin{tabular}{cccc}
\hline \multirow{2}{*}{ Name } & \multirow{2}{*}{ Type } & \multicolumn{2}{c}{ Colour at } \\
& & $2{ }^{\circ} \mathrm{C}$ & $480^{\circ} \mathrm{C}$ \\
\hline Komló & Andesite & greyish black & yellowish grey \\
\hline Nógrádkövesd & Andesite & greyish black & brownish \\
\hline Recsk & Andesite & greyish black & rusty brown \\
\hline Szob & Andesite & greyish black & rusty brown \\
\hline Tállya & Andesite & greyish black & reddish grey \\
\hline Uzsa & Basalt & greyish black & brownish \\
\hline Gánt & Dolomite & white & pinkish \\
\hline Iszkaszentgyörgy & Dolomite & jonquil & pinkish \\
\hline
\end{tabular}

physical properties of aggregates, not only their mechanical properties.

7 Colour changes were observed as additional results of bitumen content analysis. Most of the aggregates have changed their colours after heating.

\section{References}

1 Hajpál M, Török Á, Mineralogical and colour changes of quartz sandstones by heat, Environmental Geology 46 (2004), no. 3-4, 311-322, DOI 10.1007/s00254-004-1034-z.

2 Collins-Garcia H, Mang T, Roque R, Choubane B, Alternative Solvent for Reducing Health and Environmental Hazards in Extracting Asphalt: An Evaluation, Transportation Research Record: Journal of the Transportation Research Board 1712 (2000), no. 1, 79-85, DOI 10.3141/1712-10.

3 Isacsson U, Huayang Z, Relationships between bitumen chemistry and low temperature behaviour of asphalt, Construction and Building Materials 11 (1997), no. 2, 83-91, DOI 10.1016/S0950-0618(97)00008-1.

4 Almássy K, Examination of Mechanical Properties in Unbound Road Bases, Per. Pol. Civil Eng. 46 (2002), no. 1, 53-69.

5 Pethö L, Influence of temperature distribution on the design of pavement structures, Per. Pol. Civil Eng. 52 (2008), no. 1, 45-53.

6 Gómez-Heras M, Figueiredo C, Varas MJ, Maurício A, Buergo MÁ, Aires-Barros L, Fort R, Fracture and Failure of Natural Building Stones: Digital Image Analysis Contribution to the Evaluation of the Mechanical Decay of Granitic Stones Affected by Fires, Springer Netherlands, 2006.

7 Behrens ML, Dvorak BI, Woldt WE, Comparison of Asphalt Extrac- tion Procedures: Implications of Hidden Environmental and Liability Costs, Transportation Research Record: Journal of the Transportation Research Board 1661 (1999), no. 1, 46-53, DOI 10.3141/1661-08.

8 Hajpál M, Fracture and Failure of Natural Building Stones: The Behaviour of Natural Building Stones by Heat Effect, Springer Netherlands, 2006.

9 Palade LI, Attané P, Camaro S, Linear viscoelastic behavior of asphalt and asphalt based mastic, Rheologica Acta 39 (2000), no. 2, 180-190, DOI 10.1007/s003970050018. 